\title{
Perception of European nurses of culturally-appropriate health care - a cross-sectional study
}

\author{
Martin Červený', Leilani A. Siaki², Paula McGee ${ }^{3}$, Mária Kilíková' \\ ${ }^{1}$ Department of Health Sciences, St. Elizabeth University of Health and Social Sciences, Bratislava, Slovak Republic \\ ${ }^{2}$ Center for Nursing Science and Clinical Inquiry, Madigan Army Medical Center, United States \\ ${ }^{3}$ Birmingham City University, United Kingdom
}

Červený M, Siaki A, McGee P, Kilíková M. Perception of European nurses of culturally-appropriate health care - a cross-sectional study. Med Og Nauk Zdr. 2019; 25(1): 27-32. doi: 10.26444/monz/102392

\begin{abstract}
Introduction and objective. Increased migration within Europe is leading to rapid population changes in every country. Nurses increasingly care for patients with whom they do not share a common culture or language. The aim of this study is to ascertain nurses' perceptions of difficulties in providing culturally appropriate care.

Materials and method. Survey questions derived from the literature were translated from Slovak into 5 languages, then distributed to nurses in 25 European States. The survey sample consisted of 1,264 respondents from 25 European countries. Statistical analysis was performed by IBM SPSS version 18.

Results. Over $60 \%$ of nurses regularly cared for patients from different cultures. $70.6 \%$ of nurses declared challenges during nursing care for patients from different culture. The main challenges were language, religion, and lack of cultural knowledge. Statistical significance was demonstrated in terms of the preparedness of nurses to provide culturally appropriate care. Multilingual nurses were statistically significantly better prepared for nursing care of patients from other cultures.

Conclusions. Despite existing standards and guidelines, nurses working in European countries who regularly care for migrant populations do not perceive themselves to be adequately prepared to deliver culturally appropriate care. A multifaceted approach that includes policymakers, educators, and clinicians is needed. This study highlights the challenges experienced by nurses in Europe which can be informative for educational programmes for nurses and other healthcare professionals.
\end{abstract}

\section{Key words}

culturally competent care, Europe, transcultural nursing, challenges

\section{INTRODUCTION}

Increased migration within and into Europe is transforming the population of every country in the region. The Schengen Agreement, which came into force in 1995, allows the free movement of European Union (EU) nationals between most member states [1]. Refugees fleeing conflict zones, persecution and disaster areas, as well as economic migrants seeking better opportunities, have all contributed to inward migration into European states. Consequently, even countries with little previous history of immigration have increasingly diverse populations whose members originate from different parts of the world. These population changes pose challenges for healthcare providers. For example, effective communication and providing appropriate care is very difficult when patients and professionals do not share a common language or cultural background $[2,3]$.

Research focused on health inequalities conducted by the European Union Agency for Fundamental Rights (FRA) [4] revealed enormous deficiencies in the following areas: multidimensional inequality in health care provision, discrimination against ethnic minority patients, misinformation about patients from other cultures, lack of accessible interpreters in health care facilities, and

Address for correspondence: Martin Červený, Department of Health Sciences, St. Elizabeth University of Health and Social Sciences, Bratislava, Kósu Schoppera 22, 048 01, Rožňava, Slovak Republic

E-mail: m.cerveny.m@gmail.com

Received: 16 November 2018; Accepte: 28 December 2018 unpreparedness of healthcare professionals to cope with patients from diverse cultural backgrounds.

In 2015, an international work group of transcultural nursing experts developed the American Nurses Association's (ANA) first Standard for Culturally Congruent Practice, and prompted a "Call to Action" for registered nurses worldwide [5]. In the call, there was included a recommendation for nurses to become knowledgeable about existing standards and guidelines and evaluate and implement culturally congruent care in their practice. Education in transcultural nursing within the common European Economic Area (EEA) is governed by the 2013/55 / EU Directive. However, this directive does not specify the subject's curriculum [6].

This study reports the results of a survey completed by nurses from 25 European countries regarding their perceptions of the issues involved in caring for patients from culturally diverse backgrounds.

Theoretical framework of transcultural nursing. Madeleine Leininger pioneered the field of transcultural nursing; her theory of Culture Care Diversity and Universality, and the Sunrise Enabler are based on the concepts of holistic health, i.e. bio-psycho-social and spiritual well-being. Among the major tenets of Leininger's theory that inform about interactions with patients from different cultures, are health, culture, culture care, culture care and social structure dimensions, as well as worldview $[7,8]$.

According to Leininger, health is "a state of well-being that is culturally defined and constituted" [9], a state in which people 
are capable of carrying out everyday activities. Enabling others to achieve this state requires nurses to understand the socio-cultural factors that define, influence and drive health. Examples include religious and philosophical ideas, economics, education, technology, political, and legal factors. Language is a particularly important issue with regard to health and health care. Clear communications between health professionals and health consumers is crucial. In addition to Leininger, transcultural nursing knowledge was further developed by other theoreticians, like Davidhizar, Giger [10], Campinha-Bacote [11], Purnell [12], Papadopoulos, Tilki and Taylor [13]. These more recent theoreticians have expanded the field and developed educative tools to enhance nurses' ability to care for patients of diverse cultures. However, gaps remain.

Historically, the preparedness of nurses in Europe to care for patients from different cultures may be linked to recent immigration trends. Kačorová et al. [14] divided European countries into 3 groups. The first group consisted of countries with a long history of contacts with diverse cultures via former colonial empires: Portugal, Spain, France and the UK. The second group consisted of countries which became multicultural due to migration trends after the Second World War. This group included the Scandinavian countries [15, 16] and Switzerland [14]. The third group included countries with little or no previous experience with immigration. These included countries in Eastern Europe and Ireland where the transformation from a mono-cultural to a multicultural society brought about recent dramatic changes [17].

\section{OBJECTIVE}

European inward migration poses challenges for nurses who may not share a common language or cultural background with the patients for whom they provide care. The aim of this survey was to explore clinical nurses' perception of challenges that prevented or hindered the provision of culturally appropriate care.

\section{MATERIALS AND METHOD}

This study was descriptive, cross-sectional and involved European nurses directly involved in clinical practice. Nurses were surveyed across the European Union (EU) which consists of 28 countries, with a population of over 510 million, and includes many diverse languages and cultures. Consequently, a survey seemed to offer the best method of reaching a large sample of nurses. The limitations of survey research were recognized. For example, the reliability of methods of distribution may vary. People may not respond, may not complete the task fully or may pass questionnaires to others for completion. However, the survey method was used as this method is easily distributed, less time consuming, and the results can be processed objectively.

The questionnaire was developed specifically for this study. Developing the questionnaire began with a review of pertinent literature focused on transcultural nursing and the challenges health care providers encounter when delivering culturally appropriate care. Questions were developed, in the Slovak language, based on the outcomes of this review.
Once the questionnaire was finalised in the Slovak language, it was translated into the English, German, Hungarian, Polish and Italian languages. Translations were conducted by professional translators who spoke Slovak and had relevant certifications for one or more of the target languages.

The process included two independent translations from which the final version was created. This was subsequently back-translated into the source language, and compared with the original Slovak version. In the second phase, questionnaires in foreign languages were validated by using piloting. Two native speakers in English, German, Polish, Hungarian and Italian languages were invited to pilot the testing of the translated questionnaires. Changes were made to the questionnaire based on the findings from the pilot study. The most mistakes were found in the German questionnaire, for example, questionnaires were translated according to the grammar rules. Despite this, native speakers showed that they understood what was written in the german questionnaries yet hinted that it was written convolutedly.

The questionnaire contained six questions. Questions in the final version were organised around four topics.

Demographics. These included the geographic location of the respondents.

Interaction between nurses and patients from different cultures. With the focus on how frequently respondents cared for patients from cultures other than their own, and how often they experienced challenges when caring for patients from different cultures.

Challenges in nursing patients from different cultures. Examples in this topic included religion, language, lack of knowledge about culture prejudice against patients from other cultures, patients' distrust of the health care and the patient's special needs. For the subjective evaluation of the challenges, the respondent had the opportunity to express their opinion on 4-step Likert scale: highly occurring, substantially occurring, a less significant challenge or no challenge.

Subjective view of preparedness of nurses to deliver culturally appropriate health care. These questions focused on the preparation of nurses and whether they perceived culturally appropriate care. The last two questions in the questionnaire were addressed to respondents who already had 10 or more years of nursing practice. To determine the subjective evaluation, a 5-step Likert scale was used, ranging from 1 - indicating not ready, to 5 - indicating maximum readiness.

Sample and distribution of the questionnaire. Recruitment began with emails to local nursing organizations or associations in each country. If the response was positive, further work was maintained with a local contact in that country. If this was not possible, the researchers attempted to contact other organizations, nursing publications and individuals in the country concerned. These contacts were then asked to send e-questionnaires to their professional colleagues via email. A professional colleague was defined as an individual currently working as a nurse in any setting 
(e.g. hospital, school, outpatient clinic) either full or part time. The sample for this study consisted of 1,264 respondents from 25 European countries.

Ethical considerations. All ethical principles outlined by the World Medical Association [18] were adhered to. The participants were given information regarding the purpose and voluntary, anonymous nature of this survey. Completion of the questionnaire was considered consent. No personally identifiable data or health information was collected.

Data analysis. For analysis of the answers obtained from questionnaires, the following statistical methods were applied: Descriptive statistics, Mann Whitney U test (for 2 independent variables) and Kruskal Wallis test - One-way ANOVA (for more than 2 independent variables - number of languages, territory of respondent, types of challenges). Statistical analysis was performed by statistical package IBM SPSS version 18 .

\section{RESULTS}

The number of valid questionnaires received according to country is summarized in Table 1 . The largest number of responses were received from Central Europe $(n=762)$, the least from Western Europe $(n=59)$. The mean number of respondents` years in clinical practice was 14.41 years.

Table 1. Number of respondents from European countries

\begin{tabular}{|c|c|c|}
\hline European territory & Country & n (\%) \\
\hline \multirow{5}{*}{ Northern Europe } & Denmark & $54(4.27)$ \\
\hline & Finland & $1(0.08)$ \\
\hline & Iceland & $80(6.33)$ \\
\hline & Norway & $1(0.08)$ \\
\hline & Sweden & $69(5.46)$ \\
\hline \multirow{4}{*}{ Western Europe } & Belgium & $2(0.16)$ \\
\hline & United Kingdom & $38(3.01)$ \\
\hline & Ireland & $16(1.26)$ \\
\hline & The Netherlands & $3(0.24)$ \\
\hline \multirow{7}{*}{ Middle Europe } & Austria & $119(9.41)$ \\
\hline & Czech Republic & $114(9.02)$ \\
\hline & Germany & $166(13.13)$ \\
\hline & Hungary & $122(9.65)$ \\
\hline & Poland & $117(9.25)$ \\
\hline & Slovakia & $123(9.73)$ \\
\hline & Switzerland & $1(0.08)$ \\
\hline \multirow{9}{*}{ Southern Europe } & Andorra & $1(0.08)$ \\
\hline & Croatia & $2(0.16)$ \\
\hline & Cyprus & $1(0.08)$ \\
\hline & Greece & $3(0.24)$ \\
\hline & Italy & $217(17.17)$ \\
\hline & Malta & $3(0.24)$ \\
\hline & Portugal & $1(0.08)$ \\
\hline & Slovenia & $2(0.16)$ \\
\hline & Spain & $8(0.63)$ \\
\hline
\end{tabular}

Interactions among nurses and patients from different cultures. Respondents were asked how frequently they cared for patients from cultures other than their own. Responses showed that $36.16 \%$ did so every day, $19.94 \%$ once a week, and a further $25.08 \%$ at least once a month. Only $1.74 \%$ stated that they had never provided nursing care for a patient of different culture.

Challenges in nursing patients from different cultures. Respondents were asked about whether cultural differences between nurses and patients affected the provision of nursing care. Responses differed. A total of $28.96 \%$ stated that there were no challenges. However, $38.13 \%$ reported some minor difficulties and $32.91 \%$ reported major problems. These problems were attributed to language challenges (44.9\%), lack of knowledge about other cultures (35.19\%), patients' religious beliefs (30.18\%), and nurses' preconceptions about patients from other cultures (26.50\%). However, the degree to which these were thought to affect nursing care varied considerably. Results are listed in Table 2.

Differences in perception of challenges across European territories. In this survey, 895 respondents (70.9\%) from 1,264 respondents perceived challenges when caring for patients from different cultures. Results of testing for significance with differences in types of challenges are summarized in Table 2.

Table 2. Differences in perception of types of challenges across the European territories

\begin{tabular}{lc}
\hline & $\begin{array}{c}\text { Kruskal-Wallis test } \\
\text { (p-value) }\end{array}$ \\
\hline $\begin{array}{l}\text { Lack of knowledge about culture is the same across } \\
\text { European territories }\end{array}$ & 0.0001 \\
\hline $\begin{array}{l}\text { Patient's religious beliefs is the same across European } \\
\text { territories }\end{array}$ & 0.0001 \\
\hline $\begin{array}{l}\text { Language challenges are the same across European territories } \\
\text { Nurses' preconceptions are the same across European }\end{array}$ & 0.001 \\
\hline $\begin{array}{l}\text { territories } \\
\text { territories }\end{array}$ & 0.004 \\
\hline $\begin{array}{l}\text { Distrust to health care is the same across European territories } \\
\text { Demands of patient to special satisfying are the same across }\end{array}$ & 0.0001 \\
\hline \begin{tabular}{l} 
European territories \\
\hline
\end{tabular} & 0.0001 \\
\hline
\end{tabular}

Differences in perception of challenges were statistically significant across European territories, with the exception of accessibility to health care $(\mathrm{p}=0.117)$.

Subjective view of nurses' preparedness to deliver culturally appropriate care across European territories. Statistically significant differences were found in the preparedness of nurses among European territories. Nurses from Western, Northern and Southern Europe were better prepared for nursing care for patients from other countries, compared with Central Europe (Tab. 3).

Preparedness of nursing staff regarding knowledge of languages 10 years ago, and at the time of their study, was the same $(p=0.55)$. The preparedness 10 years ago and at the present time show statistically significant differences across European territories (0.001). Results of this study indicate that preparedness depends on the number of languages $(\mathrm{p}=0.001)$. 
Table 3. Subjective preparedness of nurses to care for patients according to the number of languages and across European territories

\begin{tabular}{lc}
\hline & $\begin{array}{c}\text { Kruskal-Wallis test } \\
\text { ( } \mathrm{p} \text {-value) }\end{array}$ \\
\hline $\begin{array}{l}\text { Previous preparedness of respondents (10 years ago) was the } \\
\text { same across the number of languages }\end{array}$ & 0.550 \\
\hline $\begin{array}{l}\text { Current preparedness of respondents is the same across the } \\
\text { number of languages }\end{array}$ & 0.001 \\
\hline $\begin{array}{l}\text { Previous preparedness of respondents (10 years ago) was the } \\
\text { same across European territories }\end{array}$ & 0.001 \\
\hline $\begin{array}{l}\text { Current preparedness of respondents is the same across } \\
\text { European territories }\end{array}$ & 0.001 \\
\hline
\end{tabular}

The graphical presentation of testing according to territories (item 3 ) is demonstrated in Figure 1 and, according to the number of languages, in Figure 2.

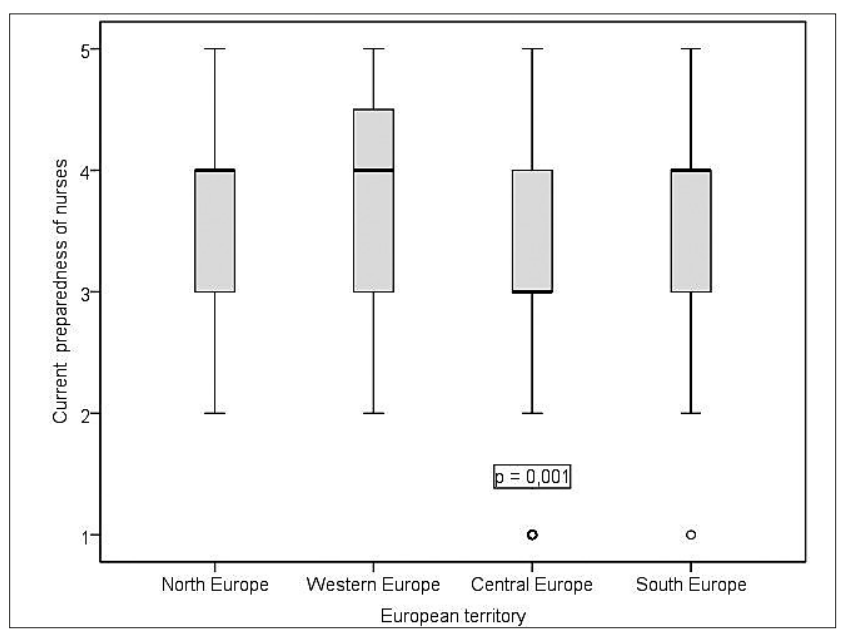

Figure 1 Current preparedness for nursing patients from different culture across European territories $(p=0.001)$

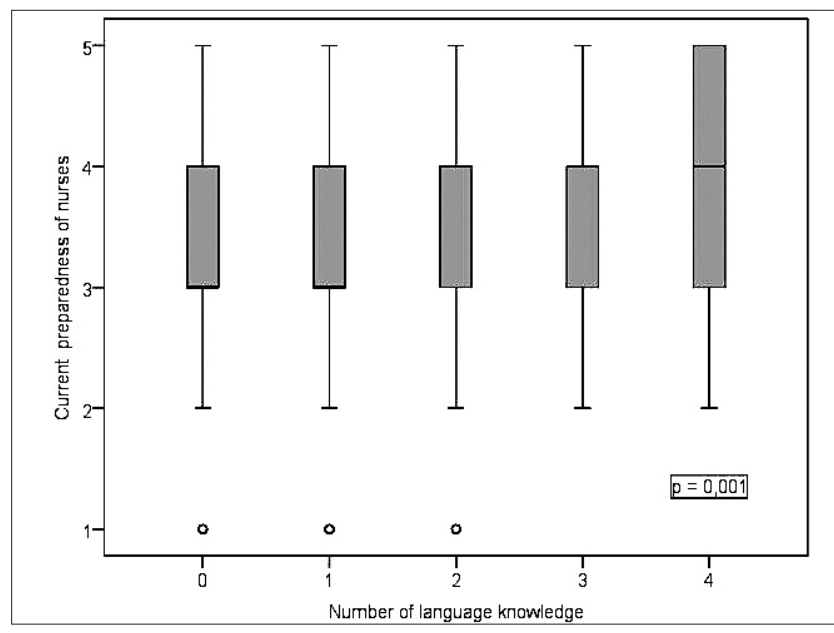

Figure 2. Current preparedness for nursing patients from different cultures according to number of languages $(p=0.001)$

Testing the influence of duration of practice for challenges and perceived preparedness. No differences were found in the perception of preparedness or challenges according to duration of practice (Tab. 4).
Table 4. Duration of practice and perception of preparedness and challenges

\begin{tabular}{lc}
\hline & $\begin{array}{c}\text { Mann-Whitney test } \\
\text { (p-value) }\end{array}$ \\
\hline $\begin{array}{l}\text { Grading challenges in nursing is the same across duration of } \\
\text { respondent practice }\end{array}$ & 0.94 \\
\hline $\begin{array}{l}\text { Previous preparedness of nurses (10 years ago) is the same } \\
\text { as duration of respondent practice }\end{array}$ & 0.12 \\
\hline $\begin{array}{l}\text { Current preparedness in nursing is the same across duration } \\
\text { of respondent practice }\end{array}$ & 0.42 \\
\hline
\end{tabular}

\section{DISCUSSION}

This study explored the challenges encountered by European nurses when caring for patients from different cultural backgrounds, aided by Leininger's transcultural nursing theory. The results showed that across Europe, nurses encountered 3 main challenges: language, religion, and cultural knowledge. Nurses' preconceptions about patients from diverse cultures also affected the provision of nursing care. Ethnocentric feelings or stereotypes complicated the delivery of care to patients from other cultures [19]. It was found that lack of a shared language was a major factor affecting patient care. This finding is consistent with those of previous studies. For example, Kuševova [20] found that language challenges were the most significant problem in providing nursing care for patients in asylum camps. Ryska and Botíková [21] found that language challenges deterred nurses from working with patients from other cultures.

Inadequate culturally appropriate care is known to contribute to healthcare disparities and suboptimal outcomes, particularly among vulnerable populations, such as immigrants. While research in this area remains limited, progress is being made $[22,5]$. Research $[15]$ undertaken in Sweden focused on nurses' interactions with children from diverse cultures. Findings showed that the nurses lacked knowledge about the children's culture, which resulted in educational courses directed at providing culturally appropriate care. Healthcare professionals from Ireland were not adequately prepared for problems they encountered while treating patients from another culture. Due to research and identified deficiencies, the Irish government implemented several educational activities [17]. In their study, Ruddock and Turner [23] found that despite the rise of multiculturalism in Denmark, their health education and health system stayed mono-cultural. Hart and Mareno [24] reported that nurses expressed their frustration about their inability to work within professional standards, along with limited resources, to address the individual needs of a growing population of migrant patients in a south-eastern state of the USA.

The aim of this survey was to discover how nurses perceive culture-appropriate care for patients from different cultures.

The current migration of people in the European Union is affecting all Member States. This survey statistically demonstrates that sessions with more language skills have experienced less subjective challenges in treating a patient from a different culture. It was also noted that there is a statistically significant difference in the current readiness of nurses from Western, Northern and Southern Europe to Central Europe, to nursing care in patients from other cultures. Further, based on the results of statistical testing, 
it can also be concluded that differences in perception of challenges are statistically significant across European regions, with the exception of accessibility to health care.

Implications for Nursing \& Health Policy. Culturallyappropriate care conveys respect for persons, impacts health disparities, and improves health outcomes $[22,5]$. However, the provision of nursing care for patients from different cultures is very demanding. Not every nurse or healthcare provider is able to meet these demands. Based on the results of this study, it is recommended that nurses apply theoretical concepts found in the Theory of Culture Care Diversity and Universality, or other transcultural theories, when developing healthcare interventions. For policy makers and healthcare leaders, the following are recommended: a) implementing training programmes focused on providing culturally appropriate care; b) supporting the development of international cooperation in research projects for this field; and c) supporting development of readily available healthcare-focused language courses.

The results from this study are in alignment with the ANA's Standard 8, and underlines the recommendations in the Call to Action.

Limitations of the study. Several limitations were identified in this study. Not all countries within the EU were represented. Less than 10 responses were received from about half of the participating countries, limiting generalization. The immigration status of respondents themselves was unknown, potentially impacting on the results. The results highlight some of the challenges in attempting to survey nurses across the EU which comprises twenty-eight countries and an increasing number of languages. There is no single mechanism through which nurses can be contacted as part of research projects. The International Council of Nurses, based in Geneva, is a member organization for nursing associations worldwide; however, not every country is a member, even in the EU, and not all nurses are members of their country's nursing organization. Additionally, the specific type, length, and methods of cultural competence training received, were not collected.

The questionnaire used was developed specifically for this study and translated into multiple languages. While questions were based on relevant literature, more research is needed to determine the reliability and validity of the instrument. It is planned to repeat this study in the future to include respondents from all EU Member States. Also under consideration is whether to expand the demographic questions to include the immigration status of the nurses themselves, and questions about actual training received.

\section{CONCLUSIONS}

Despite existing standards and guidelines, nurses working in European countries who regularly care for migrant populations do not perceive themselves to be adequately prepared to deliver culturally-appropriate care. More research is needed to evaluate current training programmes, determine what gaps exist, and how best to address these gaps. A multifaceted approach that includes policymakers, educators, and clinicians is needed.

\section{Conflict of Interests}

The authors declare that there are no conflicts of interest. Disclaimer: The views expressed in this presentation are those of the author(s) and do not reflect the official policy or position of the Department of the Army, Department of the Defense, or the US Government

\section{Acknowledgement}

First of all, I would like to express my gratitude to co-authors Leilani A. Siaki, Paula McGee, and Maria Kilíková. This article could not be published without your support. Furthermore, I would like to express my gratitude to the doc. PhDr. Lucia Dimunová, PhD. for her supporting consultations, critical contribution, and to the doc. RNDr. Pavel Matula, CSc. for his technical cooperation in the statistical elaboration of outputs.

\section{REFERENCES}

1.Eurostat. EU population up to almost 512 million at 1 January 2017. http:// c.europa.eu/eurostat/documents/2995521/8102195/310072017-AP-EN.pdf/a61celca-1efd-41df-86a2-bb495daabdab. (access: 2018.10.12)

2. Klímová M, Rosková L. The economic consequences of the contemporary European migration crisis on the Czech Republic. Kontakt. 2017; 19(4): e253-e262; http://dx.doi.org/10.1016/j.kontakt.2017.09.011.

3. World Health Organization. [Closing the Gap in a generation: health equity through action on the social determinants of health. Final report of the Commission on Social Determinants of Health]. http://apps.who. int/iris/bitstream/handle/10665/69832/WHO_IER_CSDH_08.1_slo.pd f;jsessionid=439B2DFB0B44EEA9AFDF3D67CBF79977 sequence $=8$ (access: 2018.10.11). Slovak

4. European union agency for fundamental rights. Inequalities and multiple discrimination in access to and quality of healthcare. Luxembourg: Publications Office of the European Union; 2013.

5. Marion L, Douglas M, Lavin M, Barr N, Gazaway S, Thomas L, Bickford C. Implementing the New ANA Standard 8: Culturally Congruent Practice. OJIN. 2016; 22(1): 9. doi: 10.3912/OJIN.Vol22No01PPT20.

6. European Parlament. Directive 2013/55/EU of the European Parliament and of the Council of 20 November 2013 amending Directive 2005/36/ EC on the recognition of professional qualifications and Regulation (EU) No 1024/2012. Official Journal of the European Union. 2013; 56(12): L354. doi: 10.3000/19770677.L_2013.354.eng.

7. Leininger M, McFarland MR. Culture Care Diversity and Universality: a Worldwide Nursing Theory, 2nd ed. Sudbury (MA) Jones and Bartlett Publishers, 2006.

8. Červený M. [The fundamental concepts of transcultural nursing]. Nővér. 2016; 29(5): 1-44. Hungarian.

9. McFarland M, Wehbe-Alamah H. Leininger's Culture Care Diversity and Universality: a Wordwide Nursing Theory. 3rd ed. Boston (MA) Jones \& Bartlett, 2015.

10. Giger NJ. Transcultural Nursing: Assessment and Intervention. 7th ed. St. Louis (MO) Elsevier, 2017.

11. Campinha-Bacote, J. The process of cultural competence in the delivery of health care services: A culturally competent model of care. 3rd ed. Cincinnati $(\mathrm{OH})$ Transcultural C.A.R.E. Associates, 1998.

12. Purnell L, Paulanka, B. Transcultural healthcare: A culturally competent approach (3rd ed.). Philadelphia (PA) Davis Company, 2008.

13. Papadopoulos I. Culturally Competent Compassion: A guide for healthcare students and practitioners. London (UK) Routledge Books, 2018 .

14. Kačorová J, Hlubková Z, Heiderová H. [European view of transcultural nursing]. In: [Quo vadis heath service. Proceedings of the scientific and professional conference with international participation] Prešov: Fakulta zdravotníckych odborov Prešovské univerzity v Prešove; 2012. p. 95-105. Slovak.

15. Berlin A, Törnkvist L, Hylander I. Watchfully checking rapport with the Primary Child Health Care nurses - a theoretical model from the perspective of parents of foreign origin. BMC Nursing. 2010; 9(1): 1-10. doi: 10.1186/1472-6955-9-14.

16. Wikberg A, Eriksson K. Intercultural caring. An abductive model. Scand J Caring Sci. 2008; 22(3): 485-96. doi: 10.1111/j.1471-6712.2007.00555.x. 
17. Tuohy D, McCarthy J, Cassidy I, Graham, MM. Educational needs of nurses when nursing people of a different culture in Ireland. Int Nurs Rev. 2008; 55(2): 164-70. doi: 10.1111/j.1466-7657.2007.00600.x.

18. World Medical Association. Declaration of Helsinki Ethical Principles for Medical Research Involving Human Subjects. JAMA. 2013; 310(20): 2191-2194. doi: 10.1001/jama.2013.281053.

19. Almutairi FA, Aldan AA, Nasim M. Perceptions of the critical cultural competence of registered nurses in Canada. BMC Nursing. 2017; 16:47 doi: 10.1186/s12912-017-0242-2.

20. Kuševová S. [The role of a nurse in asylum center]. In. [The 1-st International Science Conference, Multicultural Dialogue in Assisting Professions 2012. Together in Diversity]. Bratislava: VŠZaSP sv. Alžbety; 2012. p. 149-153. Slovak.
21. Ryska M, Botíková A. [Nursing in theory and practice]. Praha (CZ) Ottova tiskárna, 2011. Slovak.

22. Gallagher RW, Polanin JR. A meta-analysis of educational interventions designed to enhance cultural competence in professional nurses and nursing students. Nurse Educ Today. 2014; 35(2): 333-40. doi: 10.1016/j. nedt.2014.10.021.

23. Ruddock HC, Turner S. Developing Cultural Sensitivity: Nursing students 'experiences of Study Abroad Programme. J Adv Nurs. 2007; 59(4): 361-369. doi:10.1111/j.1365-2648.2007. 04312.x.

24. Hart PL, Mareno N. Cultural challenges and barriers through the voices of nurses. J Clin Nurs. 2014; 23(15-16): 2223-32. doi:10.1111/jocn.12500.

\title{
Postrzeganie odpowiedniej kulturowo opieki zdrowotnej przez europejskie pielęgniarki - badanie przekrojowe
}

\author{
I Streszczenie \\ Wprowadzenie i cel. Nasilająca się w Europie migracja prowadzi do gwałtownych zmian populacyjnych w każdym z krajów. \\ Coraz częściej pielęgniarki opiekują się pacjentami, z którymi nie dzielą wspólnej kultury i języka. Celem badania było \\ ustalenie postrzegania przez pielęgniarki problemów w zapewnieniu odpowiedniej kulturowo opieki. \\ Materiały i metody. Pytania kwestionariusza wywiadu pochodzące z literatury przetłumaczono z języka słowackiego na \\ 5 języków i rozdano pielęgniarkom w 25 krajach europejskich. Badanie ankietowe objęło 1264 respondentów z 25 krajów \\ europejskich. Analizę statystyczną przeprowadzono za pomocą oprogramowania IBM SPSS wersja 18. \\ Wyniki. Ponad 60\% pielęgniarek regularnie świadczyło opiekę pacjentom pochodzącym z różnych kultur. $70,6 \%$ pielęgniarek \\ zgłosiło problemy podczas opieki pielęgniarskiej nad pacjentami pochodzącymi z innych kultur. Główne wyzwania związane \\ były z językiem, religią i brakiem wiedzy kulturowej. Wykazano istotne różnice statystyczne w zakresie przygotowania \\ pielęgniarek do świadczenia opieki odpowiedniej kulturowo. Wielojęzyczne pielęgniarki były statystycznie istotnie lepiej \\ przygotowane do opieki pielęgniarskiej nad pacjentami z innych kultur niż te, które posługiwały się tylko własnym językiem \\ ojczystym. \\ Wnioski. Wbrew istniejącym standardom i wytycznym, pielęgniarki pracujące w krajach europejskich, które regularnie \\ opiekują się migrantami, nie uważają, że są odpowiednio przygotowane do świadczenia odpowiedniej kulturowo opieki. \\ Niezbędne jest wieloaspektowe podejście obejmujące decydentów, dydaktyków i klinicystów. Badanie to podkreśla \\ wyzwania, przed jakimi stoją pielęgniarki w Europie i może dostarczyć informacji przydatnych przy opracowywaniu \\ programów edukacyjnych dla pielęgniarek i innych pracowników opieki zdrowotnej.
}

\section{ISłowa kluczowe}

opieka kompetentna kulturowo, Europa, transkulturowa opieka pielęgniarska, wyzwania 